\title{
船の傾斜によるレーダーの方位誤差について
}

\section{On the Deck Tilt Error of the Marine Radar}

\section{生司和宠(商船大学)}

\section{I ま光がき}

船が傾斜しを時、PPI 亿表示されを物標の方位には誤差があることは、既に明らかをてとであ るが、実際と、動摇の甚しん小型船でとの現象が著しく、映像が歪んだ図形で表われるとんら話 も三三聞かされを所である。

ての愦差につんては MIT のシリーズの第 2 巻及びもつと詳しくは第 26 巻に述べられている

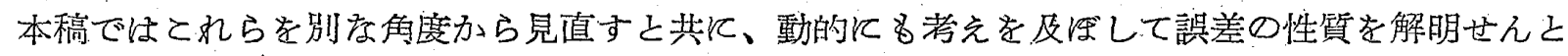
試みをものである。

\section{II 誤差の一般式}

一般式の誘導には、

1、球面三角法による法

ロ、ベクトルの考充による法

の二者が考えられるが、イ、の球面三角法によるには種ふの公式学組合わせなければねら好を、 複雑で煩しい。それK比べロの方法忹、順を迫つて攻めて行げるので楽である。MIT シリーズ

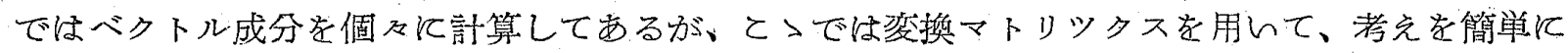
進めて行之方法によつを。

第一図で $\mathrm{O}$ を船の傾斜の中心、OB が船首方向とし、各符号を次のよ5反是める。

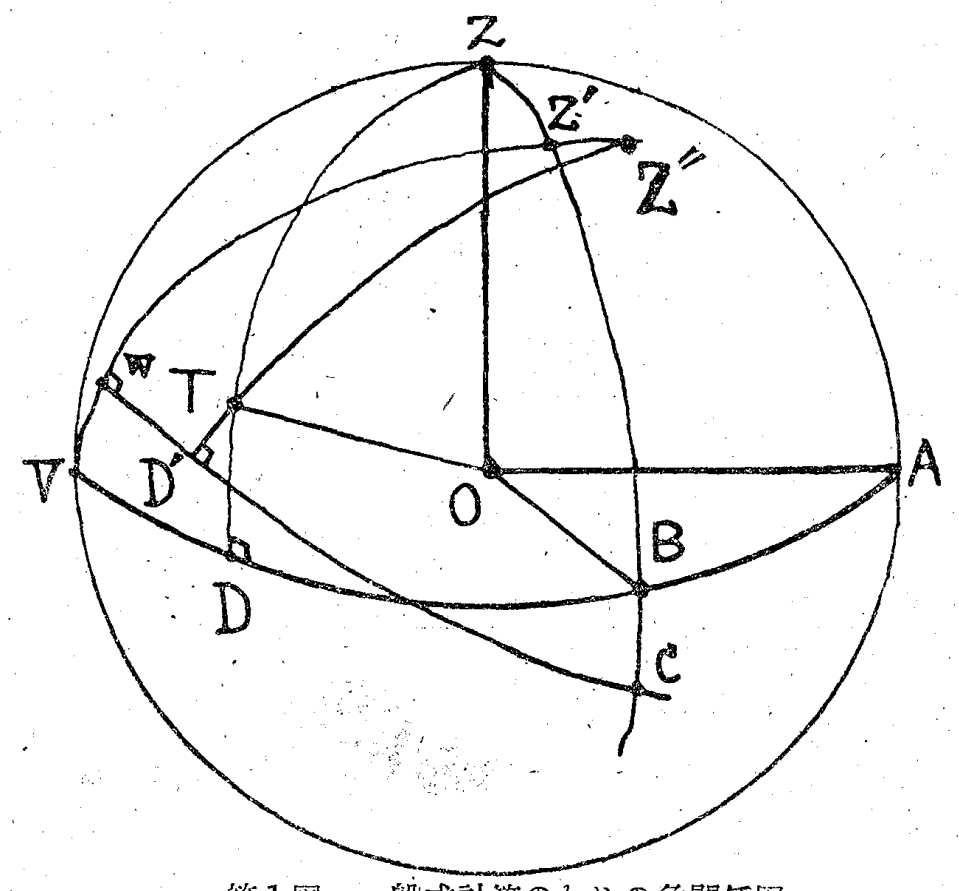

第1図一般式計賞のための苚関係图
OV 右䑨方向

OA 左舫方向

$\mathrm{OZ}$ 天頂方向

OT 物標方向

そこで船が而な゙け前傾して見わけの

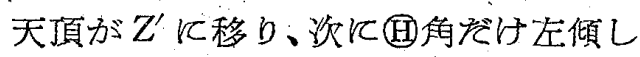
てZ゙K見かけの天頂が移つをとする。 スキャナーは傾いを軸 $\mathrm{OZ}$ "の周り反回 転して物標を探知するので方位俱差が 生するのである。即ち、物標の

真の方位角はBDであつててれを $\theta$ 真の高度は DTであつててれを、a とする。

との時傾いたOZ"軸から見れば、 見かけの方位侩社 $\mathrm{CD}^{\prime}=\theta^{\prime}$ 見かけの高度は $D^{\prime} \mathrm{T}=\mathrm{a}^{\prime}$ 


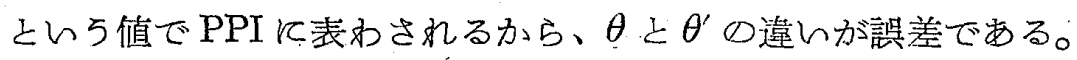

$\theta$ と $\theta$ の関係式が得られればよん。

OTを単位の長さとして、ベタトル OTを xyzの三成分で表はすととにし、先和 $\mathrm{x}$ 軸は OT 方向

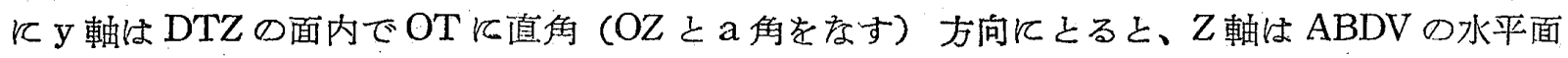

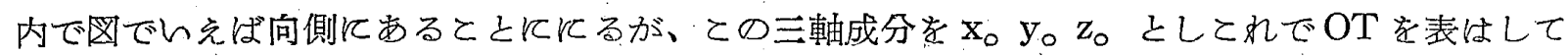
$V_{0}$ とする。

$$
V_{\circ}=\left|\begin{array}{l}
x_{0} \\
y_{0} \\
z_{\circ}
\end{array}\right|=\left|\begin{array}{l}
1 \\
0 \\
0
\end{array}\right|
$$

今のxyz 系を、Z軸の周bに ( - a ) 角だけ迴転させを系で表わして、その三成分を $\mathrm{x}_{1} \mathrm{y}_{1} \mathrm{z}_{1}$ 之

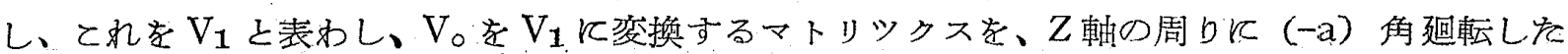
系に変換すると亡走すため、 $\mathrm{A} z(-\mathrm{a})$ 亡すれば次の式が成立つ。

$\mathrm{V}_{\mathbf{1}}=\mathrm{Az}(-\mathrm{a}) \cdot \mathrm{V}_{0}$

これで $x_{1}$ 軹は OD方向に来た。

㳄に $y_{1}$ 軸の周bに $\theta$ 角置わすと $x_{2}$ 軸は $\mathrm{OB}$ 方向に来る。

$Z_{2}$ 軸の周bK $(-\Phi)$ 角迴わして OC 方向K

$x_{3}$ 軸の周bK (一具) 角廻わして

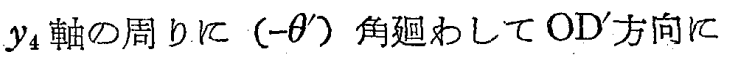

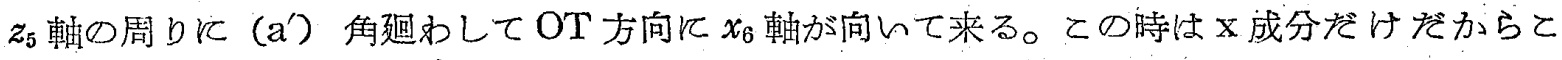
の時 $\mathrm{V}_{6}$ とすれば、これる

$$
V_{6}=\left|\begin{array}{l}
x_{6} \\
y_{6} \\
z_{6}
\end{array}\right|=\left|\begin{array}{l}
1 \\
0 \\
0
\end{array}\right|
$$

とをる。

以上のととを式でわせば、

$$
\mathrm{V}_{6}=\mathbf{A z}\left(\mathbf{a}^{\prime}\right) \cdot \mathbf{A y}\left(-\theta^{\prime}\right) \cdot \mathbf{A x}(-\Theta) \cdot \mathbf{A z}(-\Phi) \mathbf{A y}(\theta) \cdot \mathbf{A z}(-\mathrm{a}) \cdot \mathrm{V}_{\circ}=\left|\begin{array}{l}
1 \\
0 \\
0
\end{array}\right|
$$

(2)式の変換マトリックスを入れれば、

$$
\begin{aligned}
& V_{6}=\left|\begin{array}{cccc}
\cos a^{\prime} & \sin a^{\prime} & 0 \\
-\sin a^{\prime} & \cos a^{\prime} & 0 \\
0 & 0 & 1
\end{array}\right| \cdot\left|\begin{array}{ccc}
\cos \theta^{\prime} & 0 & \sin \theta^{\prime} \\
0 & 1 & 1 \\
-\sin \theta^{\prime} & 0 & \cos \theta^{\prime}
\end{array}\right| \cdot\left|\begin{array}{ccc}
1 & 0 & 0 \\
0 & \cos (\Theta) & -\sin (\Theta) \\
0 & \sin (\Theta) & \cos (\Theta)
\end{array}\right| \cdot \\
& \cdot\left|\begin{array}{ccc}
\cos \Phi & -\sin \Phi & 0 \\
\sin \Phi & \cos \Phi & 0 \\
0 & 0 & 1
\end{array}\right| \cdot\left|\begin{array}{ccc}
\cos \theta & 0 & -\sin \theta \\
0 & 1 & 0 \\
\sin \theta & 0 & \cos \theta
\end{array}\right| \cdot\left|\begin{array}{ccc}
\cos a & -\sin a & 0 \\
\sin a & \cos a & 0 \\
0 & 0 & 1
\end{array}\right| \cdot\left|\begin{array}{l}
1 \\
0 \\
0
\end{array}\right|=\left|\begin{array}{l}
1 \\
0 \\
0
\end{array}\right|
\end{aligned}
$$

(3)式を計算して次の $(4)(5)$ 式党得る。

$\tan \theta^{\prime}=\frac{(\sin (\Theta) \sin \Phi \cos \theta+\cos (\mathrm{H}) \sin \theta) \cos a+\sin (\Theta) \cos \Phi \sin a}{\cos \Phi \cos \theta \cos a-\sin \Phi \sin a}$

$\sin a^{\prime}=(\cos (\Theta) \sin \Phi \cos \theta-\sin ($ (1) $\sin \theta) \cos a-\cos ($ (A) $) \cos \Phi \sin a$

(5)式は高展測定用レーダーに必要であるが、船舶用レーダーでPPI J式のものには関係な no

(4)式ををとにしていろいろな場合につんて考えて見るとよよする。 


\section{III 物標か水本線附近にある場合}

(4)式に於レて $a$ を 0 とした時得られるもので、

$\tan \theta^{\prime}=\sin (\mathrm{H})+\frac{\cos (\mathrm{H})}{\cos \Phi} \tan \theta$

(6)式から

$\tan \left(\theta^{\prime}-\theta\right)=\frac{\sin (\theta) \sin \Phi+(\cos (\Theta)-\cos \Phi) \tan \theta}{\cos \Phi+\sin (\Phi) \sin \Phi \tan \theta+\cos \left(\Theta \tan ^{2} \theta\right.}$

(7)式のよ5にして愦差が得られる。又誤差が最大になる方位を $\theta_{m}$ とすれば、(7)式より $\tan \theta_{m}=\frac{\sin (\mathrm{H}) \cos (\mathrm{A}) \sin \Phi \pm(1-\cos (\mathrm{A}) \cos \Phi) \sqrt{\cos (\mathrm{H}) \cos \Phi}}{(\cos (\mathrm{A})-\cos \Phi) \cos (\mathrm{A})}$

(8)式が得られる。

以上縦傾斜亡橫傾斜の二者が存在して傾斜しを状態のものであるが、これを別ふと考えて見 ると、

i. 横傾斜のみの場合、

(6)、(7)、(8)式に於んて $\Phi$ 老 $O$ 亡したものである。次の三つの式が得られる。 $\tan \theta^{\prime}=\cos (\operatorname{tin} \theta$

$$
\begin{aligned}
& \tan \left(\theta^{\prime}-\theta\right)=\frac{(1-\cos (\mathrm{A})) \tan \theta}{1+\tan ^{2} \theta \cos (\mathrm{A})} \\
& \tan \theta_{m}=+\frac{1}{\sqrt{\cos (\mathrm{H})}} \ldots \ldots \ldots \ldots \ldots \ldots \ldots \ldots
\end{aligned}
$$

第 2 図は見かけの方位 $\theta^{\prime}$ を横軸沉とつて、田が夫及 $10^{\circ} 20^{\circ} 30^{\circ} 40^{\circ}$ の時の $\theta-\theta^{\prime}=\Delta \theta の く ゙$ らふである。

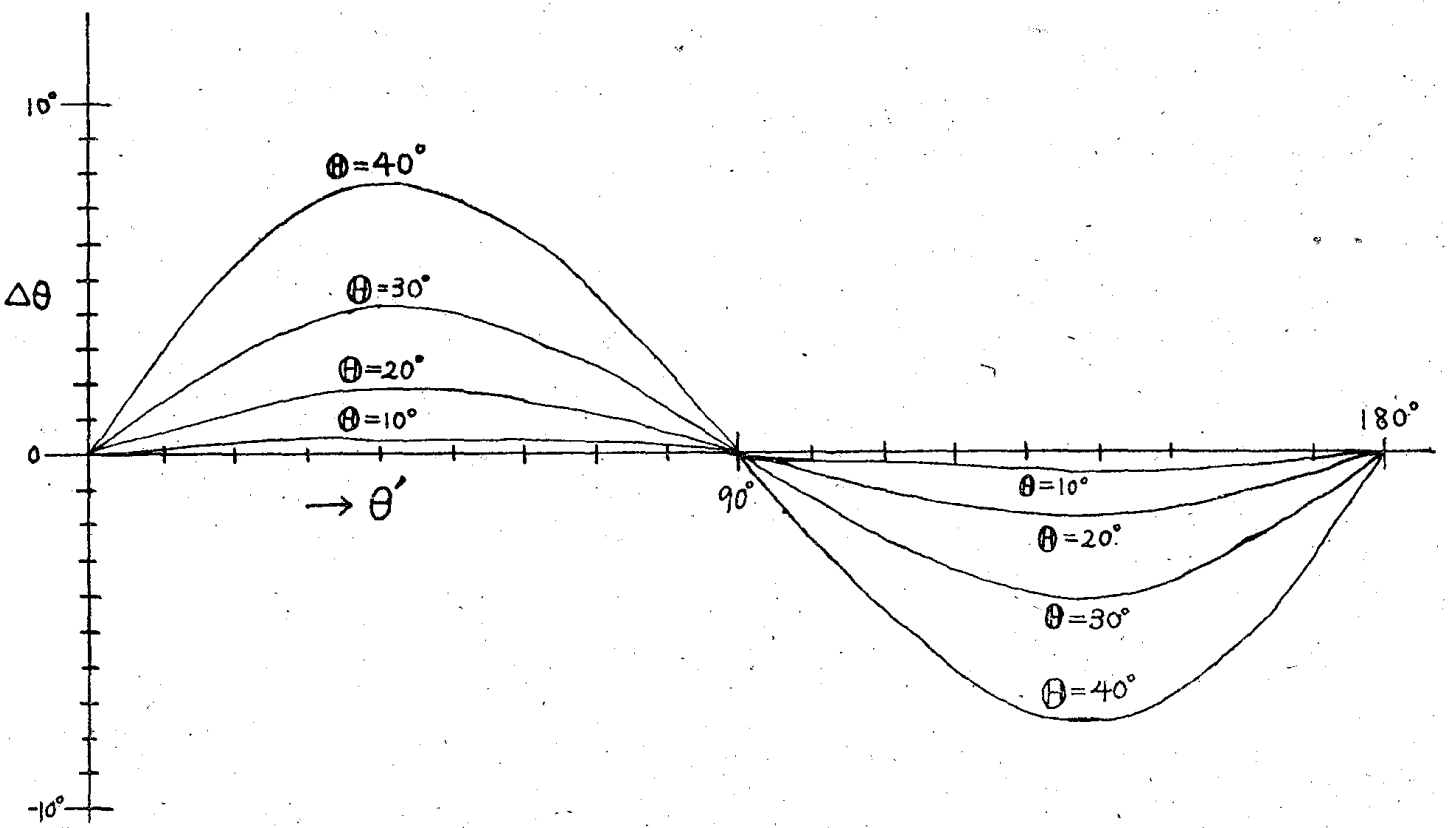

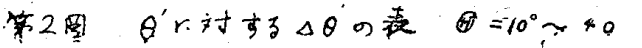




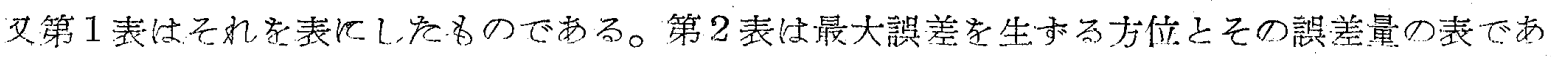
る。

第1表 $\theta^{\prime}$ 亿対する $\Delta \theta\left(=\theta-\theta^{\prime}\right)$ の表、単位度、(而は在䑪傾斜が十

\begin{tabular}{|c|c|c|c|c|c|c|c|c|c|c|c|c|c|c|c|c|c|c|}
\hline$\theta^{\prime}$ & $0^{\circ}$ & $10^{\circ}$ & $20^{\circ}$ & $30^{\circ}$ & $40^{\circ}$ & $50^{\circ}$ & $60^{\circ}$ & $70^{\circ}$ & $80^{\circ}$ & $90^{\circ}$ & 1000 & $110^{\circ}$ & $120^{\circ}$ & $130^{\circ}$ & $140^{\circ}$ & $150^{\circ}$ & 160.0 & $170^{\circ}$ \\
\hline $10^{\circ}$ & 0 & +0.2 & +0.3 & +0.4 & +0.4 & +0.4 & +0.4 & +0.3 & +0.2 & 0 & -0.2 & -0.3 & -0.4 & -0.4 & -0.4 & -0.4 & -0.3 & -0.2 \\
\hline $20^{\circ}$ & 0 & +0.6 & +1.2 & +1.6 & +1.8 & +1.7 & +1.5 & +1.1 & +0.6 & 0 & -0.6 & -1.1 & -1.5 & -1.7 & -1.8 & -1.6 & -1.2 & -0.6 \\
\hline $30^{\circ}$ & 0 & +1.5 & +2.8 & +3.7 & +4.1 & +4.0 & +3.4 & +2.5 & +1.3 & 0 & -1.3 & -2.5 & -3.4 & -4.0 & -4.1 & -3.7 & -2.8 & -1.5 \\
\hline $40^{\circ}$ & 0 & +3.0 & +5.4 & +70 & +7.6 & +7.3 & +6.1 & +4.4 & +2.3 & 0 & -2.3 & -4.4 & -6.1 & -7.3 & -7.6 & -7.0 & -5.4 & -3.0 \\
\hline
\end{tabular}

・ 第2表 最大誤差を生杏る方位の表

\begin{tabular}{|c|c|c|c|}
\hline (1) & $\theta_{m}$ & $\theta^{\prime} m$ & $\triangle$ \\
\hline $10^{\circ}$ & 45.2 & 44.8 & 0.4 \\
\hline $20^{\circ}$ & 45.9 & 44.1 & 1.8 \\
\hline $30^{\circ}$ & 47.1 & 42.9 & 4.2 \\
\hline $40^{\circ}$ & 48.8 & 41.2 & 7.6 \\
\hline $50^{\circ}$ & 51.3 & 38.7 & 12.6 \\
\hline $60^{\circ}$ & 57.8 & 38.4 & 19.4 \\
\hline
\end{tabular}

-ii 縦傾斜のみの場合

(6)（7）(8)式に於んて田を $O$ として得られ、

$$
\tan \theta^{\prime}=\frac{\tan \theta}{\cos \Phi}
$$

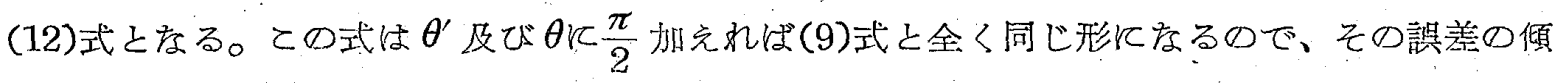

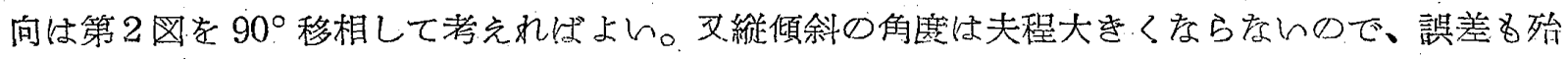
どとるに后らっん量である。

\section{VV物標の高度を考光なければならない場合}

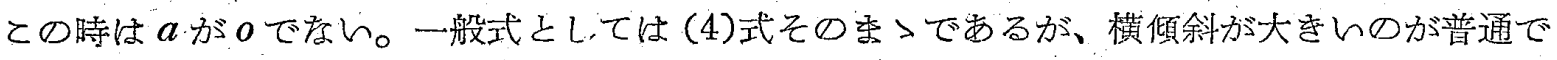
あるので、横傾斜だけある場合、即らのが 0 である場合を考えると、(4)式から整理して、(13) 式を得る。

$$
\tan \theta^{\prime}=\tan \theta \cos (\mathbb{A})+\frac{\sin \Theta}{\cos \theta} \tan a
$$

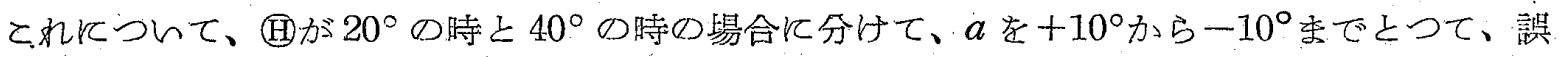
差の量を方位角の函数として表わしたぐらふが第 3 図と第 4 四でする。

てのぐらふ考見て注目すべき点は、一の高度の物標に対しては、大き教愦差が出ていることで

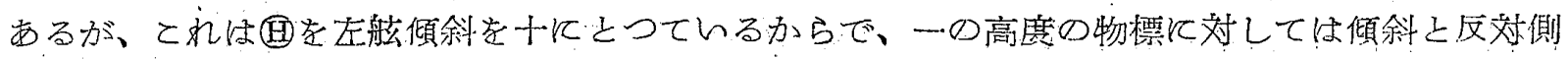
の舷の物標の愦差が大をんてとを示している。 


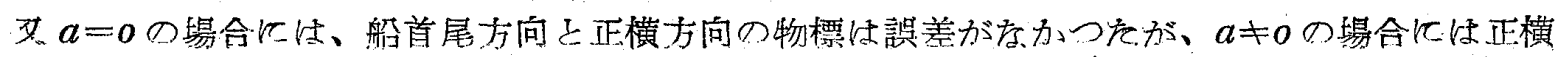
カ向では誤差が 0 だが船首尾力向では誤差があるこ上である。
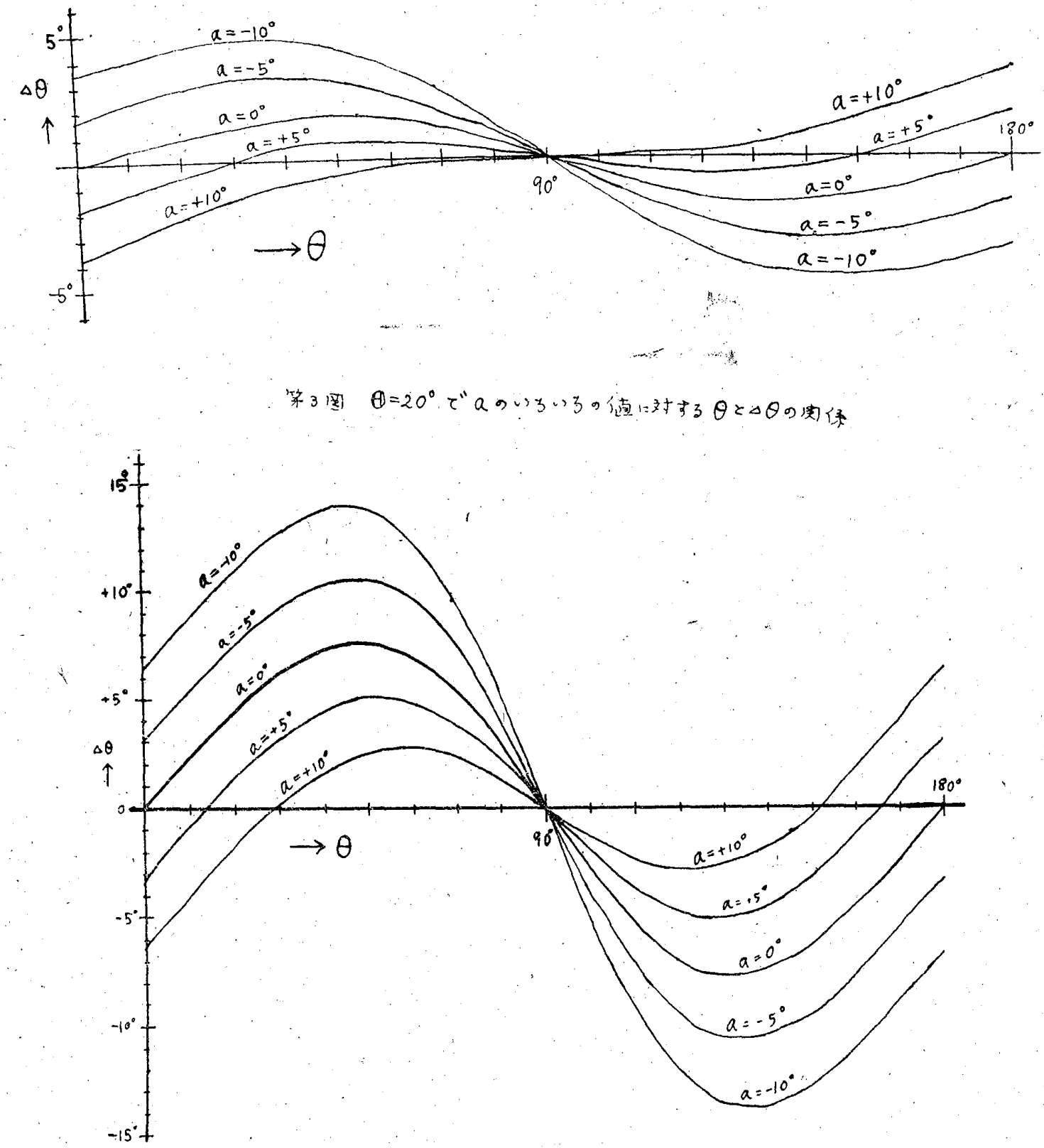

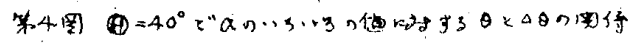

$\nabla$ (田と $\Phi$ の両方が存在する時の考光方

第 5 図で、 $Z^{\prime} Z^{\prime \prime}=$ (再 $Z Z Z^{\prime}=\Phi$ とする。

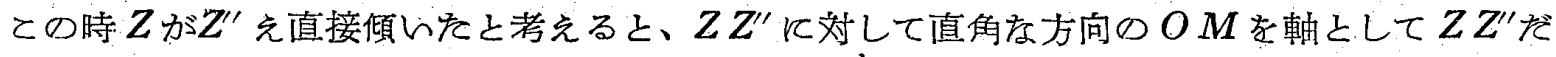
け横傾斜したとして考えてよんわけである。全べての方位を $O M$ 軸中心に考えて、第 2 浪、“第 3 圀、第 4 四のカーブの出発点を移動させて画を始め机ばよんととになる。

乙の㭙 $B M=\theta$ 。は見かけのローリング軸の方位角

$Z Z^{\prime \prime}=\boldsymbol{\rho}$ は見かけの横傾斜角

$\theta_{\circ}^{\prime}-\theta_{\circ}=C M-B M$ は見加け摇船首角 


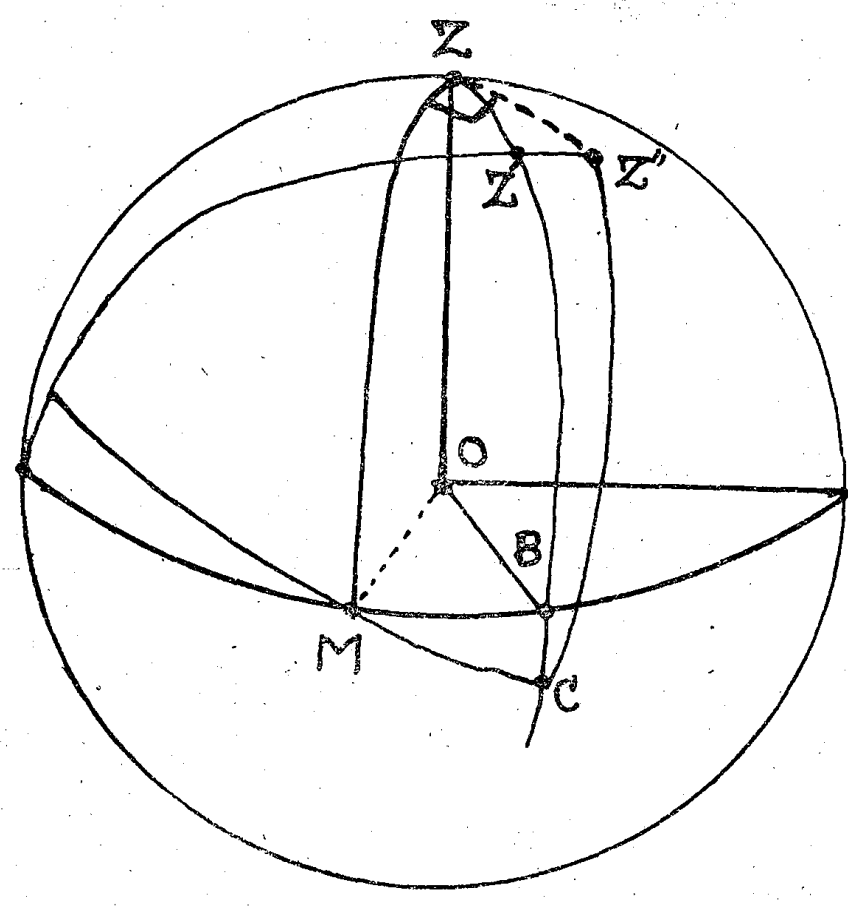

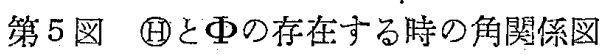

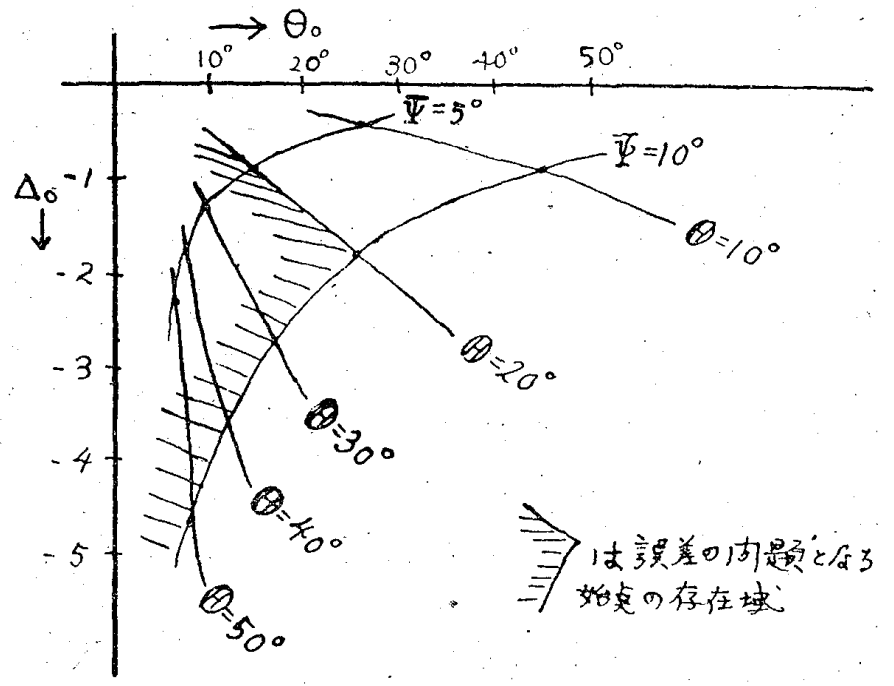

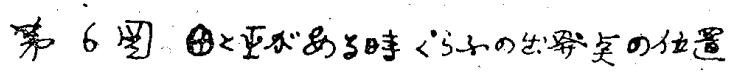

と呼ぶて上が出来る。とれら老部算すれ ば、

$\tan \theta_{\mathrm{o}}=\sin \Phi \cot$ (1)

$\cos \phi=\cos$ (A) $\cos \Phi$

$\tan \left(\theta_{\circ}^{\prime}-\theta_{0}\right)=\frac{\sin \Theta \sin \Phi}{\cos (\Theta) \cos \Phi}$

を得る。とれをぐらふにしをのが第 6

困で表にしをものが第3表である。

\begin{tabular}{|c|c|c|c|c|c|c|c|c|}
\hline$\Phi$ & \multicolumn{3}{|c|}{$5^{\circ}$} & \multicolumn{3}{|c|}{$10^{\circ}$} \\
\hline 10 & $\theta_{\circ}$ & $\theta_{\circ}^{\prime}$ & $\Delta$ & $\varphi$ & $\theta_{\circ}$ & $\theta_{\circ}^{\prime}$ & $\Delta$ & $\rho$ \\
\hline 20 & 13.5 & 14.3 & -0.9 & 20.6 & 25.5 & 27.3 & -1.8 & 22.3 \\
\hline 30 & 8.6 & 9.9 & -1.3 & 30.4 & 16.7 & 19.4 & -2.7 & 31.5 \\
\hline 40 & 5.9 & 7.7 & -1.8 & 40.3 & 11.7 & 15.3 & -3.6 & 41 \\
\hline 50 & 4.2 & 6.5 & -2.3 & 50.2 & 8.3 & 13.0 & -4.7 & 50.7 \\
\hline
\end{tabular}

第 3 表 第 6 図の表

\section{VI. 結，論}

\section{i 愦差の性筫}

船の傾斜した状態に於ける場合と、動 摇状態に於ける場合に分けて侾えると上 が必要であるが、ん秃の場合も共通し て次のようをことが言える。

一般得䛩最大の方位は $40^{\circ} \sim 50^{\circ}$ の方 向である。だからこの方向にある物標の 方位をとる時は注意を要するし、海岸線 等の図形す歪んで表われるととに注意す べきである。

$\Phi の$ 量に比し间の方が一般船船では大 きんから、両者の存在する場合でも、注 意の大きい力位山 $45^{\circ}$ 附近となるととは、 $V$ 節から推察される所である。

船用レーダーとして物標探知の場合、その構造上十の高度よりも一の高度の物標を表わす場合 が多ん。即らスキャナ高約 $20 \mathrm{~m}$ とれば、1 浬の距離にある物標の高度は約一 $0.6^{\circ}$ で $1 \mathrm{~km}$

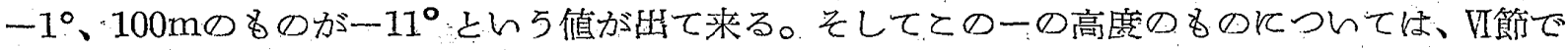

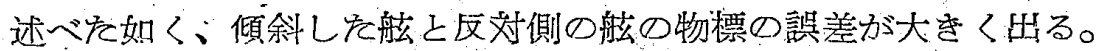

以上の上ら疗点であるが次に、Static の場合とDinamic の場合につんて、どんな図形が $P$ PI 亿表われるかを考えて見るととにする。

ii Static D膓合 


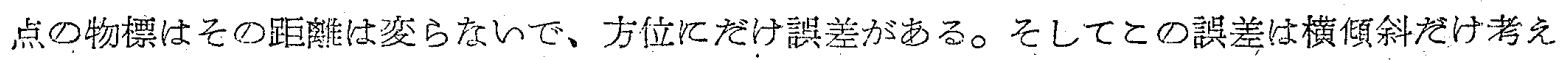
そ場合(10)式に示されたように、方位の函数で西る。

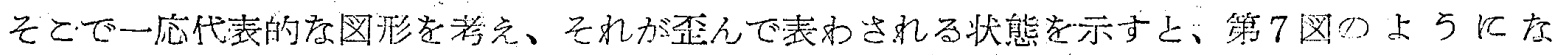

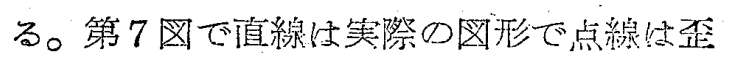
んで表われる線である。乙れは而が $40^{\circ} の$ 場合のbのである。

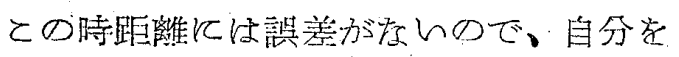
中心亡する円は歪なく円に表わされるが、

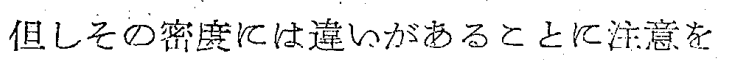
要する。即方譟差は方位の函数であるが、 一方舶用レーダーではスキやナが一是速悬 で回転しているのであるから、方位红時䦓

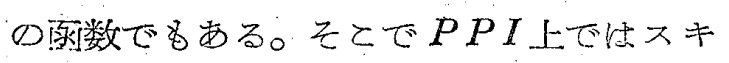
ヤナ回転速度が不整一亲スキャナの昌のを 是速のブラウン管指示器に表わしそ加くに なるのである。

iii Dinamic の皆合

Pitching は少々量鹿ので、 Rolling す る昜合につんて恬け考えるとする。

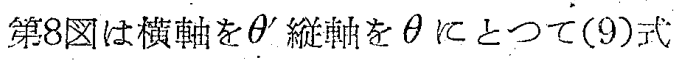

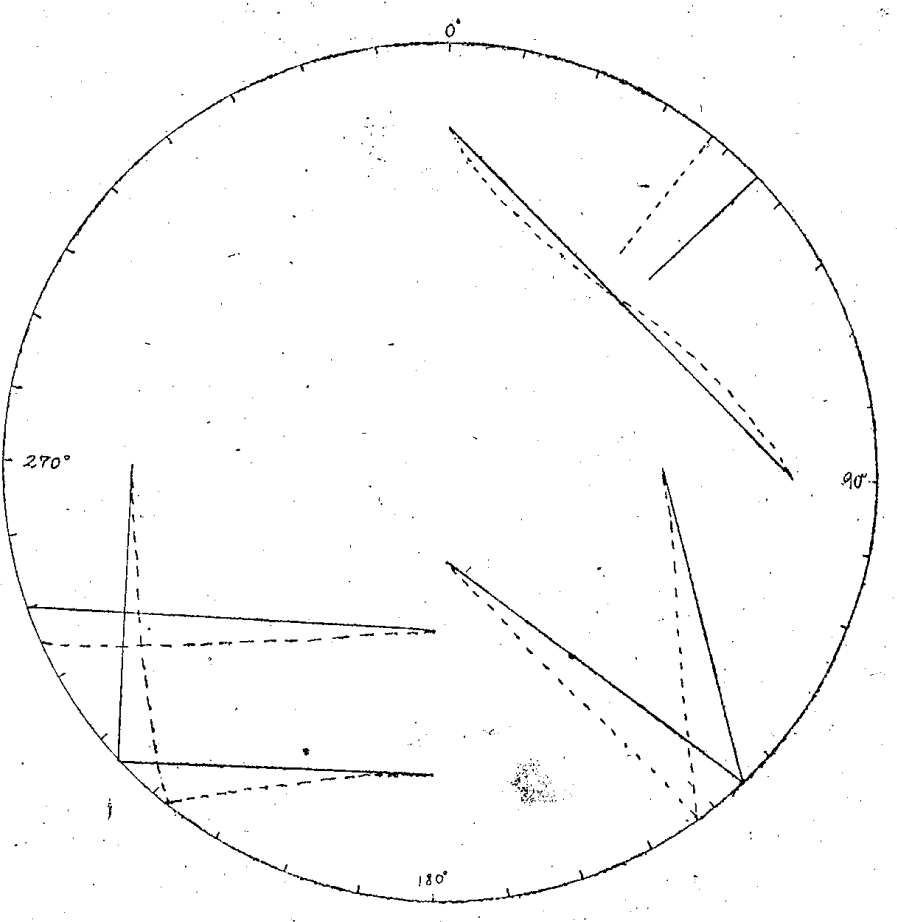

第7図 $\oplus=40^{\circ}$ の封の歪の形

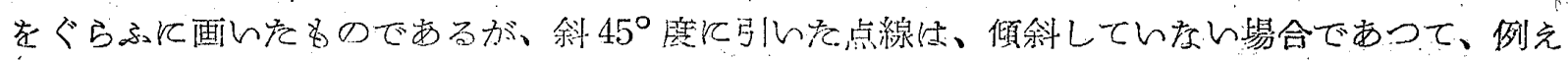

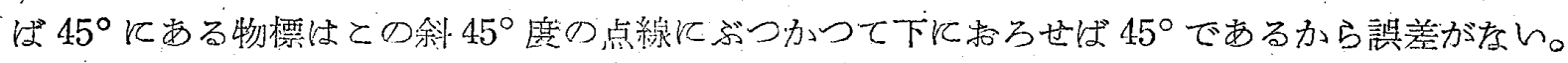

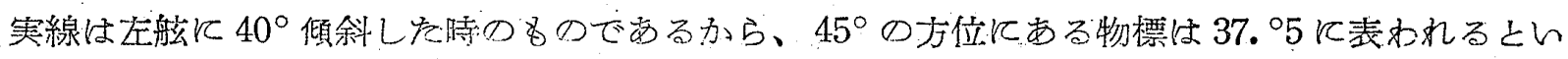

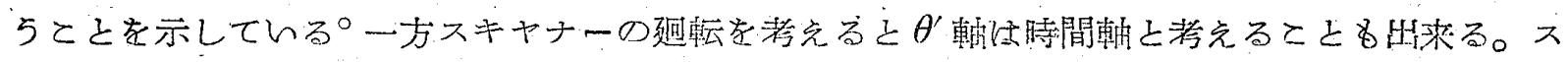
キャナーが一分䦎化 15 迴転する上すれ以゙、

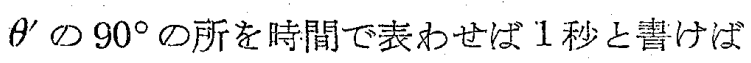
よん。そこで先积の $45^{\circ} の$ 物標が $37 . \circ 5$ 亿受 信するといらと亡注、傾斜してをい時飞此 し、見かけのスキャン速度が早くをつをとと にをり、破線は右舷傾斜の昜合だから、との

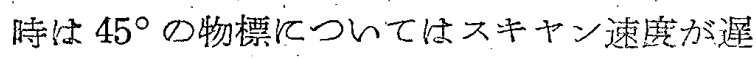
く症つたと考光られる。即马斜の直線より傾 斜が急な部分は、見かけのスキャン速䵇が増 しを所で、傾斜の緩やか虑部分㤌見かけのス キャン速度が咸つを所である。

40の Rollimg する時㤌、乙の笑線上破 線に㜀委れを区域内右に在に蛇行するカー ソが画かれるかけで、との時 Rolling の周

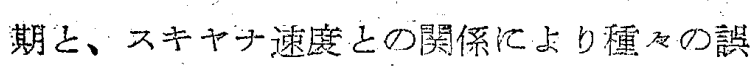
美が表われる。

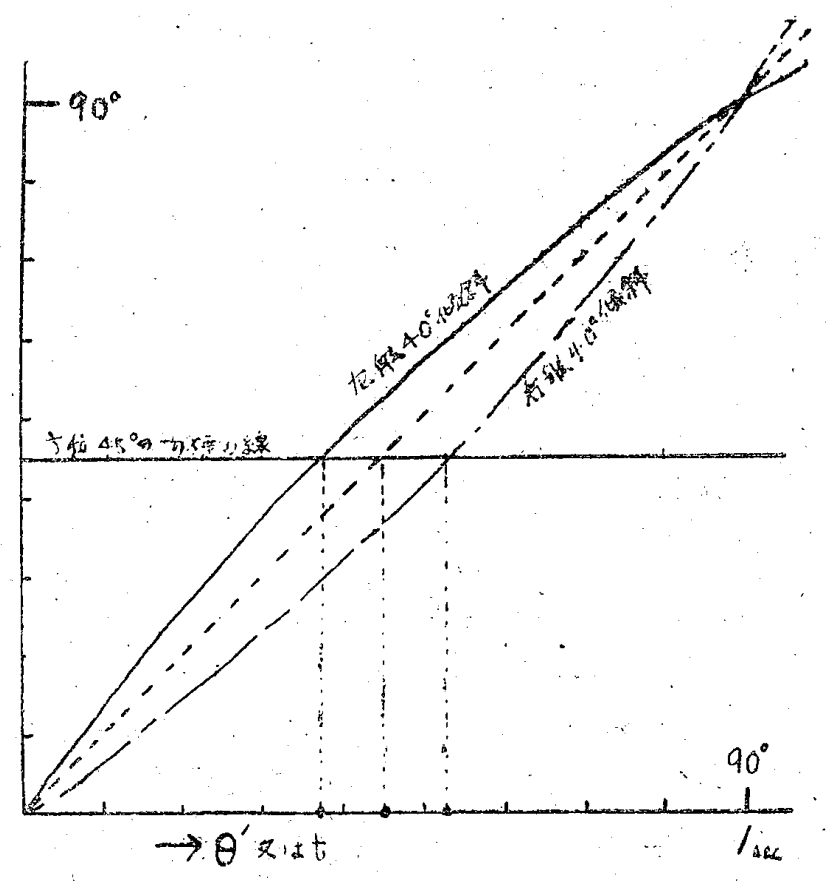

第8図 $\theta$ と $\theta$ その関䋆 


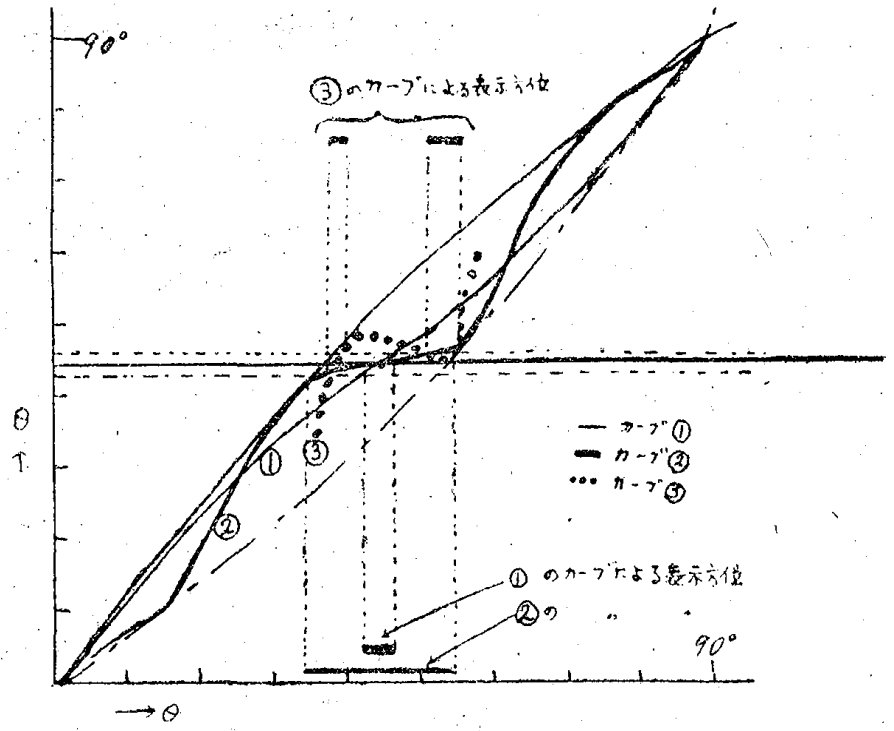

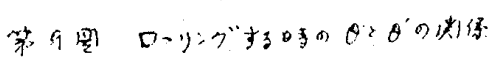

$$
\text { 与以在つてんる。 }
$$$$
n T=15
$$

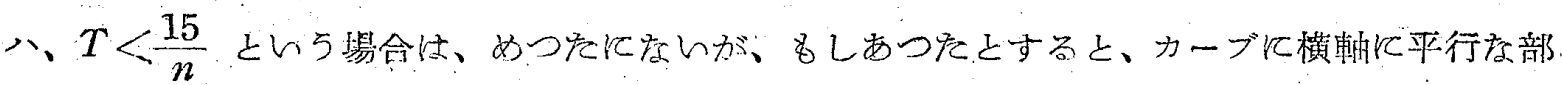

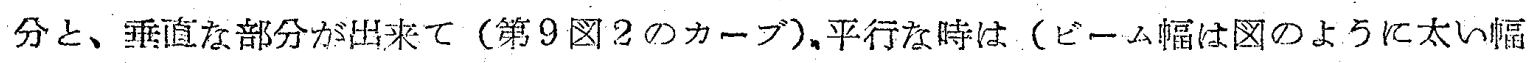
のある線として表わされこの中にカーブが入んる時）点の物標も方位幅のある線となつて表

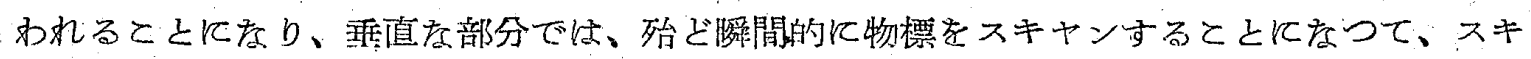

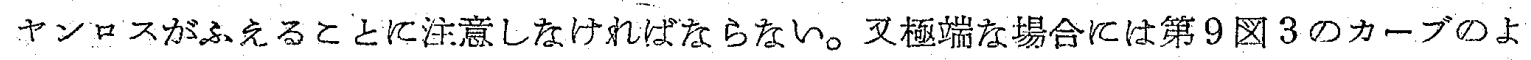

5に、1点が2つの物標に分れて表わる場合があるてとるあり得る。

iiii 以上のととから、結論されるのは Rolling の蕒しん時は物標の方位をとると注意して、 up right K船がをつを時の映像をつかをえるべをである。

刃、Rolling 周期の早い小型船には、スキャナの回転の速レレーダーを用らべきである。

\section{V 機構的な解決方法}

機構的に愦差を消去するには二つのう法が考えられる。即ちその一つは、スキャナをジンバル

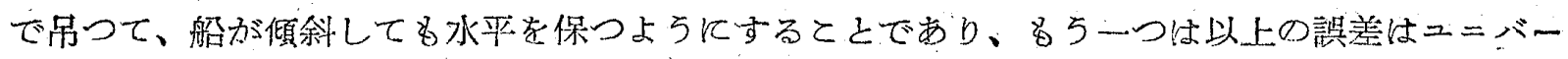

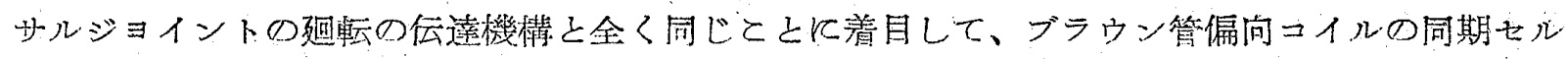
シンの発信に際し、叉はその中間にユニバーサルジョイントで結合したセルシンを置いて、ブシ ウン管偏向コイルの回転を今をで述べを見かけのスキナン速度に同期させるととである。

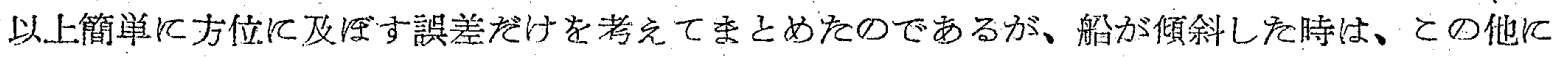

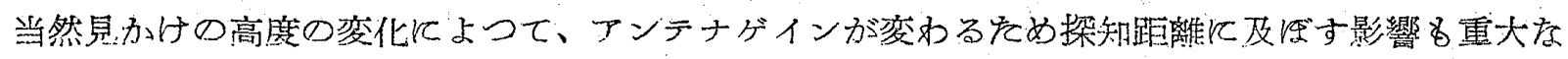

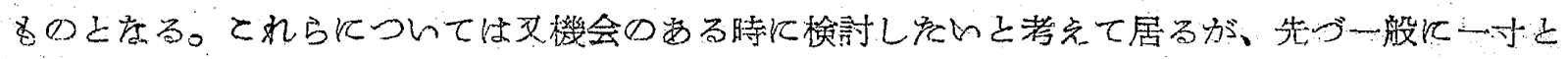

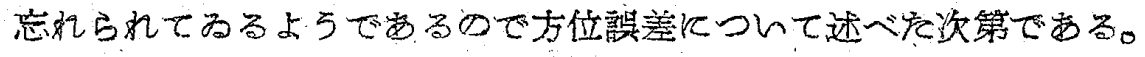

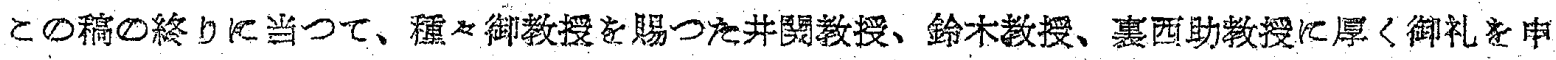
し上比票す。 